\title{
TANGGUNG JAWAB NOTARIS ATAS AKTA PERNYATAAN KEPUTUSAN RAPAT
}

\author{
Jonathan Adi Biran Munandir dan Thohir Luth \\ Program Magister Kenotariatan Fakultas Hukum Universitas Brawijaya \\ Jl. MT. Haryono No 169; Malang; 65145; Indonesia; (0341) 553898 \\ jonathan.adi32@yahoo.com
}

\begin{abstract}
The authority and responsibility of the notary on the deed of Statement of Meeting Decision and to analyze the strength of notary proof of the deed of Statement of Meeting Decision. The method used in this research is normative law research with approach method of legislation. The primary, secondary and tertiary law materials obtained by the authors will be analyzed by using literature techniques using grammatical and logical legal interpretations. The result of research with the above method indicates that Notary of Notary's responsibility to Statement of Meeting Decision is only responsible only for formal truth, while the truth of the contents of the deed is the responsibility of the parties to the notary because the notary does not know and attend the meeting. The Declaration of Decision of the Meeting includes the evidence of letters and including the "Partij Deed" category made by the general officers appointed by oath and against the verification otherwise able to be challenged, without accusing his falsehood, by stating that the statements of the parties concerned are described in full in the deed, but the information is false, meaning that the information given is permitted otherwise.
\end{abstract}

Keywords: Authority,Notary, Responsibility, Strength of Proof.

\begin{abstract}
Abstrak
Kewenangan sekaligus tanggung jawab notaris atas akta Pernyatan Keputusan Rapat dan menganalisis kekuatan pembuktian notaris atas akta Pernyatan Keputusan Rapat. Metode yang digunakan dalam penelitian ini adalah penelitian hukum normatif dengan metode pendekatan perundang-undangan. Bahan hukum primer, sekunder dan tersier yang diperoleh penulis akan dianalisa dengan mengunakan teknik kepustakaan dengan memakai interprestasi hukum gramatikal, dan logis. Hasil penelitian dengan metode di atas menunjukan bahwa tanggung jawab Notaris terhadap Pernyataan Keputusan Rapat hanya bertanggungjawab sebatas kebenaran formil saja, sedangkan mengenai kebenaran isi akta tersebut menjadi tanggungjawab para pihak yang menghadap notaris, karena notaris tidak mengetahui dan menghadiri jalannya rapat. Akta Pernyataan Keputusan Rapat termasuk alat bukti berupa surat dan termasuk golongan "Partij Akta" dibuat oleh pejabat umum yang diangkat dengan sumpah dan terhadap pembuktian sebaliknya dapat digugat, tanpa menuduh akan kepalsuannya, dengan jalan menyatakan bahwa keterangan dari para pihak yang bersangkutan ada diuraikan menurut sesungguhnya dalam akta itu, akan tetapi keterangan itu adalah tidak benar, artinya terhadap keterangan yang diberikan itu diperkenankan pembuktian sebaliknya.
\end{abstract}

Kata Kunci: Kekuatan Pembuktian, Kewenangan, Notaris, Tanggung Jawab. 
Pembangunan Nasional yang dilakukan Negara Indonesia saat ini bertujuan untuk mewujudkan suatu masyarakat adil dan makmur berdasarkan Pancasila dan Undang-Undang Dasar Republik Indonesia Tahun 1945. Tentu dibutuhkan biaya dan tenaga yang sangat besar agar jalannya pembangunan bisa berkesinambungan, baik dari pemerintah maupun badan hukum. Sebagai upaya untuk merealisasikan pembangunan tersebut. Salah satu cara mengembangkan pembangunan nasional dengan cara membuat perseroan terbatas yang merupakan salah satu badan usha dalam kegiatan perekonomian.

Perseroan terbatas adalah persekutuan yang berbentuk badan hukum, dimana Perseroan terdiri dari sero-sero atau juga dikenal saham-saham, istilah terbatas disini merujuk kepada batasan tanggung jawab persero atau pemegang saham, yaitu hanya terbatas pada jumlah nilai dari semua saham-saham yang dimiliki (Kansil, 1996).

Undang-Undang Republik Indonesia Nomor 40 Tahun 2007 tentang Perseroan Terbatas (UU PT) menempatkan notaris pada kedudukan yang tinggi, hal ini dikarenakan untuk mendirikan Perseroan Terbatas dan mengadakan perubahan anggaran dasar harus dibuat dengan akta Notaris sebagai persyaratan utama. Persyaratan tersebut sesuai dengan ketentuan Pasal 7 Ayat (1) UUPT dan Pasal 21 Ayat (4) UUPT. Berdasarkan bunyi Pasal, akta notaris merupakan syarat mutlak dan wajib dipenuhi untuk mendirikan sebuah perseroan, akta otentik adalah akta yang diwajibkan untuk dibuat dalam pendirian perseroan.

Salah satu wewenang notaris berdasarkan Undang-Undang Republik Indonesia Nomor 30 Tahun 2004 tentang Jabatan Notaris (UUJN) adalah untuk menyusun dan membuat akta otentik. Otentisitas dari akta notaris berlandaskan dari ketentuan Pasal 1 UUJN, dimana notaris dijadikan sebagai "Pejabat Umum”, sehingga dengan demikian akta yang dibuat "oleh" atau "di hadapan" Notaris dalam kedudukan tersebut memperoleh sifat akta otentik, seperti yang diatur pada Pasal 1868 Kitab Undang-Undang Hukum Perdata (KUHPerdata), dimana Pasal tersebut menyatakan bahwa akta otentik merupakan akta yang dibuat dalam bentuk yang telah diatur di dalam undang-undang, dibuat "oleh" atau "di hadapan" pejabat umum yang berkuasa untuk itu di tempat akta itu dibuat.

Akta Pernyataan Keputusan Rapat yang selanjutnya disebut (PKR) merupakan hasil dari notulen Rapat Umum Pemegang Saham (RUPS) yang dibuat di bawah tangan kemudian dituangkan ke dalam akta Notaris. Hal tersebut dapat dikuasakan kepada pihak dari Perseroan Terbatas yang bersangkutan untuk diberikan secara langsung oleh RUPS. Penerima kuasa tersebut juga dapat menemui notaris dalam rangka pembuatan PKR.

Notaris wajib memperhatikan dengan secara detail bahwa penerima kuasa tersebut memang merupakan perwakilan dari Perseroan Terbatas (PT) yang bersangkutan yang berwenang dan memiliki kecakapan untuk membuat akta tersebut (Bambang, Rianggono, 2007). Bentuk PKR tersebut merupakan akta Notaris, namun aktanya merupakan hasil keputusan rapat yang dibuat oleh notulen di bawah tangan.

Berdasarkan Pasal 21 Ayat (4) UUPT yang menyatakan bahwa memperbolehkan akta PKR dibuat oleh notaris secara akta otentik. Apabila terjadi cacat formal pada akta tersebut maka akta tersebut hanya mempunyai kekuatan bukti seperti layaknya akta di bawah tangan apabila para pihak menandatangani akta tersebut. Sesuai dengan Pasal 21 Ayat (4) UUPT tersebut tanggung jawab Notaris hanya sebatas data yang dimasukkan atau dibawa oleh notulen RUPS.

Kasus PKR tesebut adalah salah satu contoh kasus PKR yang sebenarnya diperbolehkan oleh UUPT Pasal 21 Ayat (4), ternyata di Propinsi Pekanbaru terjadi gugatan terhadap PKR yang dibuat dihadapan notaris. Hal ini yang membuat para 
notaris tidak berani mengambil atau membuat PKR tersebut. Kasus di atas tersebut angkat hanya sebagai ilustrasi, sehingga sesuatu yang sudah ditentukan oleh Undang-Undang pun masih bisa dipermasalahkan di kemudian hari.

Mengenai sejauh mana tanggung jawab notaris apabila notulen yang memberikan akta hasil rapat RUPS tidak sesuai dengan aslinya karena notaris tidak mengetahui kebenaran isi atas akta tersebut, mengingat PKR itu bukan risalah rapat notariil murni melainkan risalah rapat dibawah tangan, dimana Notaris tidak hadir atau terlibat dalam pembuatan keputusan RUPS yang dibuat dibawah tangan tersebut melainkan keputusan rapat tersebut dibuat oleh para pihak dalam perjanjian berdasarkan kesepakatan mereka yang kemudian perjanjian tersebut dibawa ke hadapan notaris untuk dituangkan kedalam akta notaris (Bambang Rianggono, 2007).

Bedasarkan latar belakang di atas dapat dirumuskan suatu masalah tentang bagaimanakah tanggung jawab notaris atas akta Pernyataan Keputusan Rapat (PKR) dan Bagaimanakah kekuatan pembuktian akta Pernyataan Keputusan Rapat (PKR) ditinjau dari Hukum Pidana dan Hukum Perdata.

\section{Metode}

Penelitian ini menggunakan metode penelitian yuridis normatif, dimana penelitian normatif akan menelaah pasal-pasal, asas dan doktrin-doktrin yang terkait dengan tanggung jawab Notaris akta Pernyataan Keputusan Rapat (PKR), dan kekuatan pembuktian atas akta Pernyataan Keputusan Rapat (PKR). Pada penelitian ini peneliti ingin memahami dan menganalisa tentang bagaimana tanggung jawab Notaris akta Pernyataan Keputusan Rapat (PKR); Untuk memahami dan menganalisa tentang kekuatan pembuktian atas akta Pernyataan Keputusan Rapat (PKR).

\section{Kewenangan dan Tanggung Jawab Notaris dalam Pembuatan Akta Pernyataan Keputusan Rapat (PKR)}

Perjanjian yang merupakan suatu perikatan yang melahirkan hak dan tanggung jawab bagi para pihak yang membuatnya. Dengan dibuatnya suatu perjanjian dalam bentuk tertulis diharapkan oleh para pihak yang membuatnya, di kemudian hari tidak ada yang memungkiri apa yang telah disepakati bersama sebagai suatu perjanjian yang mengikat para pihak satu sama lainnya (Bambang Rianggono, 2007).

Menurut Pasal 1868 KUHPerdata, akta otentik merupakan akta menurut bentuk yang ditentukan oleh undang-undang, dibuat oleh atau di hadapan pegawai-pegawai umum yang berwenang untuk itu di tempat akta itu dibuat. Kewenangan notaris dalam pembuatan akta Pernyataan Keputusan Rapat (PKR) berdasarkan selaku pejabat umum dalam melaksanakan tugasnya tercantum dalam Pasal 15 Undang-Undang Republik Indonesia Nomor 30 Tahun 2004 tentang Jabatan Notaris (Bambang Rianggono, 2007).

Menurut Undang-Undang Perseroan Terbatas suatu hasil dari RUPS dapat dibuat dalam tiap akta otentik atau di bawah tangan. Namun tidak semua hasil RUPS dibuat dalam akta otentik maka sebuah perseroan terkadang melakukan RUPS tanpa kehadiran seorang notaris, namun untuk memperkuat hasil dari RUPS tersebut organ perusahaan akan menguasakan kepada salah satu direksi untuk menuangkan putusan RUPS tersebut dalam suatu akta otentik. Hal ini yang kemudian dikenal dengan sebutan akta Pernyataan Keputusan Rapat (PKR).

Kewenangan dan tanggung jawab notaris dalam pembuatan akta Pernyataan Keputusan Rapat (PKR) ialah (Bambang Rianggono, 2007):

a. Menjamin kepastian tanggal, tanda tangan dari akta yang dibuatnya tersebut; 
b. Penghadap harus benar-benar hadir di hadapan notaris;

c. Membacakan isi akta;

d. Penandatangan akta pada hari dan tanggal sebagaimana disebutkan dalam akta;

e. Penandatangan akta di dalam wilayah jabatan notaris;

f. Menyimpan minuta aktanya;

g. Memberikan salina nakta:

h. Mencatat setiap akta yang dibuat dalam suatu buku daftar akta;

i. Mengirim salinan buku akta kepada Majelis Pengawas Daerah Notaris, setiap bulannya paling lambat pada tanggal 15 bulan berikutnya.

Dalam teori kewenangan berdasarkan atributif yang dikemukakan oleh Indroharto yaitu kewenangan yaitu pemberian wewenang pemerintah yang baru oleh suatu keadaan dalam peraturan perundang-undangan. Jadi, di sini dilahirkan atau diciptakan suatu wewenang pemerintah yang baru. Hal tersebut sesuai dengan bunyi Pasal 15 Ayat 1 UUJN dan Pasal 21 Ayat (4) Undang-Undang Republik Indonesia Nomor 40 tahun 2007 tentang Perseroan Terbatas yang menegaskan bahwa akta Pernyataan Keputusan Rapat (PKR) harus di buat secara akta Otentik.

Kewenangan yang diberikan berdasarkan atributiftersebut bermakna bahwa notaris mempunyai tanggung jawab atas apa yang telah ditentukan oleh Undang-Undang. Segala sesuatu yang dikerjakan secara sengaja atau tidak, harus dimintai pertanggungjawaban terutama yang berkaitan etika profesi dari seorang profesional di bidang hukum. Tanggung jawab dari seseorang yang memiliki profesi bidang hukum tentu berat. Hal itu berkaitan dengan tindakan seorang notaris dalam melaksanakan jabatannya, notaris juga tidak terlepas dari suatu tanggung jawab.

Terlebih profesi notaris merupakan salah satu profesi dari profesi hukum yang ada dan yang harus menjunjung tinggi nilai-nilai kode etik dalam menjalankan jabatannya. Seorang notaris dalam menjalankan jabatannya sebagai pejabat umum berkewajiban untuk turut menegakkan hukum sesuai dengan profesinya. Menyumbangkan tenaga dan fikiran pada tugasnya, harus dilakukan dengan penuh amanah, jujur, saksama, mandiri dan tidak berpihak. Dengan adanya amanah yang menyangkut kepentingan orang/pihak lain, maka tanggung jawab yang berat berada pada notaris.

Pertanggung jawaban notaris berada pada luang lingkup kebenaran materiil atas akta sudah dibuat oleh notaris. Mengenai tanggung jawab notaris selaku pejabat umum yang berhubungan dengan kebenaran materiil, dibedakan menjadi empat hal yang terdiri dari: Pertanggung jawaban terhadap jabatannya dalam hal ini adalah pada jabatan notaris itu sendiri, dengan kata lain tanggung jawab notaris terhadap akta yang dibuat adalah bersifat personal, tanggung jawab tersebut melekat pada diri pribadi notaris yang bersangkutan, kemanapun atau dimanapun notaris tersebut berada. Hal ini menjadi benar adanya, mengingat notaris yang bersangkutan tersebut, merupakan pejabat umum satu-satunya yang dituangkan ke dalam akta dengan format yang dikehendaki dan disepakati oleh para pihak.

Mengenai tanggung jawab yang harus dipikul oleh notaris berhubungan dengan kesalahankesalahan dalam menjalankan kewenangan dan kewajibannya, dalam hal ini dapat dipergunakan teori tanggung jawab berdasarkan kesalah Liability based on fault. Penerapannya, kerugian yang timbul itu disesuaikan pula apakah kesalahan yang dilakukan itu merupakan kesalah berat atau kesalahan ringan, dimana berat ringannya suatu kesalahan berimplikasi pada tanggungjawab yang harus ditanggung (H.R, 2006). Teori ini berdasarkan pada Pasal 1365-1367 KUHPerdata. UUJN dan KUHPerdata Pasal 1365-1367 secara filosofi, yuridis, dan sosiologis dapat diterima karena adil bagi orang yang berbuat salah untuk mengganti kerugian bagi pihak yang dirugikan. 


\section{Tanggung Jawab Notaris Atas Akta Pernyataan Keputusan Rapat}

Jonathan Adi Biran Munandir \& Thohir Luth

Unsur kesalahan yang dilakukan baik kesalahan perdata berupa perbuatan melwan hukum (Pasal 1365 KUHPerdata), kemudian kesalahan pidana berupa pemalsuan akta (Pasal 253, 266 Kitab Undang-Undang Hukum Pidana (KUHPidana)), rahasia jabatan (Pasal 322 KUHPidana), pemalsuan yang dilakukan oleh pejabat (Pasal 416 KUHPidana) notaris dapat diminta pertanggungjawaban baik secara perdata, pidana, UUJN maupun kode etik.

Notaris harus dimintakan pertanggungjawabannya sesuai dengan bobot kesalahan yang dilakukannya apabila terdapat kesalahan. Notaris dapat dimintakan pertanggungjawaban dan perbuatannya termasuk perbuatan melawan hukum. Meskipun notaris hanya mengakomodir para pihak yang menghadap, bukan tidak mungkin Notaris tidak melakukan perbuatan yang melanggar ketentuan hukum. Perbuatan apapun yang mengakibatkan kerugian bagi orang lain dapat diperkarakan di pengadilan (Bambang Rianggono, 2007).

Perbuatan melawan hukum dari Notaris yang menimbulkan kerugian bagi klien, dapat dijerat berdasarkan Pasal 1365 KUHPerdata yang mana maksud dari Pasal ini adalah untuk mengembalikan hak korban, setidaknya pada kondisi tidak terjadi perbuatan melawan hukum, maka akan diproses pengembalian secara nyata yang kiranya lebih sepadan disbanding sekedar pembayaran ganti rugi berupa uang, karena pembayaran dengan uang hanyalah nilai yang ekuivalen saja.

Apabila di kemudian hari terdapat sengketa antara para pihak terhadap isi akta tersebut, maka disini jika diperlukan notaris dapat diminta keterangan atau hanya sebatas memberikan kesaksian atas hal-hal yang berkaitan dengan akta yang dibuat "dihadapan" atau "olehnya" di depan pihak berwajib dalam pengadilan jika sengketa tersebut telah diajukan gugatan ke pengadilan. Notaris dikategorikan terlibat apabila di dalam akta yang bermasalah notaris tersebut mengetahui adanya syarat-syarat yang tidak sesuai dengan ketentuan yang berlaku, namun memaksakan pelaksanaan pembuatan akta, dalam hal ini notaris wajib mempertanggungjawabkan perbuatannya dan putusannya diserahkan kepada penyidik dan hakim pada persidangan.

Akta notaris dibuat hanya untuk para pihak, bukan untuk kepentingan notaris, apabila terjadi sengketa dari perjanjian yang termuat dalam akta notaris maka yang terikat adalah mereka yang mengadakan perjanjian itu sendiri, sedangkan notaris tidak terikat untuk memenuhi kewajiban apapun seperti yang tertuang dalam akta notaris yang (H.R, 2006).

Tanggung jawab notaris berasal dari undangundang sebagaimana tercantum dalam Pasal 65 UUJN. Notaris harus bertanggungjawab atas setiap akta yang dibuatnya, selama akta tersebut dibuat berdasarkan ketentuan-ketentuan tentang pembuatan akta, syarat dan isinya terpenuhi serta tidak berlawanan dengan ketentuan umum serta dapat memenuhi rasa keadilan semuah pihak terkait, maka Notaris tidak dapat diminta pertanggungjawaban atas akta tersebut (Bambang Rianggono, 2007).

Notaris dalam hal ini tidak bertanggung jawab atas akta "Pernyataan Keputusan Rapat (PKR)" yang dibuat di hadapan Notaris, karena isi akta "Pernyataan Keputusan Rapat (PKR)" tersebut berdasarkan pada notulen RUPS isinya menjadi tanggung jawab semua pihak yang hadir pada RUPS.

Notaris hanya bertanggungjawab terhadap bentuk dari akta "Pernyataan Keputusan Rapat (PKR)" secara formalitas saja sedangkan keabsahan tentang materi atau isi perjanjian beserta segala akibat hukumyang dimunculkannya, notaris tidak dapat dituntut dan diminta pertanggungjawabannya oleh para pihak, hal ini sepenuhnya menjadi tanggung jawabpara pihak yang membuat perjanjian tersebut, notaris sendiri hanya berperan dalam mendengar, melihat dan menerima keinginan para pihak dan kemudian dituangkan dalam bentuk akta, sepanjang kehendak para pihak tersebut tidak melanggar ketentuan-ketentuan umum yang ber- 
laku. Oleh karena itu, seorang notaris harus dengan sungguh-sungguh memperhatikan ketentuan hukum tentang tata cara pembuatan akta Pernyataan Keputusan Rapat (PKR) untuk menghindari permasalahan hukum di kemudian hari.

Pertanggungjawaban notaris terhadap kebenaran isi akta RUPS yang langsung dihadiri oleh Notaris (akta Berita Acara Rapat), jelas berbeda dengan pembuatan akta RUPS yang dibuat dengan notulen RUPS dibawah tangan akta "Pernyataan Keputusan Rapat (PKR)". Membuat akta RUPS yang langsung dihadiri oleh notaris yang merupakan "relaas akta", notaris berwenang dan wajib memeriksa prosedur pelaksanaan jalannya rapat tersebut sesuai tata cara mengadakan rapat tersebut sesuai dengan undang-undang perseroan (Pasal 76 UUPT), apabila ternayata rapat RUPS tersebut ternyata tidak memenuhi ketentuan dalam anggaran dasar perseroan dan undangundang, maka Notaris berhak untuk menolak pembuatan akta RUPS tersebut.

Tanggung jawab notaris dalam pembuatan akta RUPS dimana notaris hadir secara langsung aktanya biasa disebut "Berita Acara Rapat", notaris dapat dimintai pertanggungjawaban terkait benar tidaknya isi dari akta tersebut dan notaris memiliki tanggung jawab penuh terhadap isi akta tersebut, hal ini dikarenakan karena notaris melihat, mendengar serta menyaksikan secara langsung jalannya rapat, kemudian notaris mencatat keterangan dari hasil rapat tersebut yang dituangkan dalam akta RUPS yang langsung dihadiri oleh notaris (akta Berita Acara Rapat). Sehingga dalam hal ini notaris wajib lebih berhati-hati dan teliti dalam menuangkan hasil rapat tersebut ke dalam akta Berita Acara Rapat (Tobing, 1996).

\section{Kekuatan Pembuktian Notaris atas Akta Pernyataan Keputusan Rapat (PKR) Ditinjau dari Hukum Pidana}

Terdapat perbedaan antara pembuktian dalam perkara pidana dengan perkara perdata, dalam perkara pidana tujuan utamanya untuk mencari kebenaran materiil, kebenaran yang sesunggunya, sementara dalam perkara perdata tujuan utama adalah mencari kebenaran formil, dalam hal ini hakim tidak boleh melewati batas-batas yang diajukan oleh para pihak yang berperkara. Tugas hakim dalam proses pencarian kebenaran formal sebatas membuktikan dengan preponderance of evidence, sedangkan hakim pidana pada proses pencarian kebenaran materiil, maka peristiwanya harus terbukti telah terjadi atau dikenal dengan istilah beyond reasonable doubt (Sofyan\& Asis, 2014).

Hal ini juga berlaku pada persidangan dimana hakim lebih bersifat aktif dalam perkara pidana, hakim berkewajiban mendapatkan bukti yang cukup untuk membuktikan tuduhan, berbeda dibandingkan pada perkara perdata dimana hakim lebih pasif, tidak menambah dan mengurangi selain hal yang menjadi sengketa para pihak. Menurut Pasal 6 Ayat (2) Kitab Undang-Undang Hukum Acara Pidana (KUHAPidana), bahwa "Tidak seorang pun dapat dijatuhkan pidana, kecuali apabila pengadilan, karena alat pembuktian yang sah menurut undang-undang, mendapat keyakinan bahwa seseorang yang dianggap dapat bertanggung jawab, telah bersalah atas perbuatan yang didakwakan atas dirinya".

Tahapan perkara pidana sangat dimungkinkan upaya paksa dilakukan oleh aparat penegak hukum dan upaya paksa tersebut berkaitan dengan pembuktian. Pasal 1 butir 14 KUHAPidana menyatakan bahwa tersangka adalah seorang yang karena perbuatannya atau keadaannya, berdasarkan bukti permulaan, patut diduga sebagai pelaku tindak pidana. Sementara menurut Petunjuk Pelaksanaan Kepala Polisi Republik Indonesia, "bukti permulaan" sebagaimana dimaksud dalam Pasal 1 butir 14 KUHAPidana adalah berdasarkan satu macam alat bukti dan adanya laporan polisi yang dapat digunakan untuk menetapkan seseorang sebagai tersangka (Siswandi, 2017). Artinya alat bukti yang dimaksudkan disini adalah sebagaimana yang tercantum dalam Pasal 184KUHAPidana, antara 
lain (Hiariej, 2012): Keterangan saksi; Keterangan ahli; Surat; Petunjuk; dan Keterangan terdakwa.

Dalam hal ini kta Pernyataan Keputusan Rapat (PKR) dapat diklasifikasikan sebagai "Partij Akta"yang dibuat dihadapan notaris dan sekaligus merupakan salah satu jenis alat bukti berupa surat. Surat tersebut dibuat atas sumpah jabatan atau diperkuat dengan sumpah. Sebagaimana notaris, yang merupakan pejabat yang berwenang untuk membuat akta otentik dan kewenangan lainnya, notaris juga sah melakukan praktik profesinya setelah diangkat melalui sumpah atau janji menurut agamanya di hadapan Menteri atau pejabat yang ditunjuk.

KUHAPidana menganut teori pembuktian berdasar undang-undang secara negatif (negatief wettelijk). Ditegaskan dalam Pasal 183 KUHAPidana (Pasal 294 KUHAPidana), bahwa "Hakim tidak boleh menjatuhkan pidana kepada seseorang kecuali apabila dengan sekurang-kurangnya dua alat bukti yang sah ia memperoleh keyakinan bahwa suatu tindak pidana benar-benar terjadi dan bahwa terdakwalah yang bersalah melakukannya". PKR sendiri telah memenuhi dua alat bukti antara lain:

a. PKR merupakan salah satu jenis alat bukti surat atau tulisan, karen bentuk fisiknya yang dijadikan alat bukti dalam persidangan adalah tertulis.

b. Isi dari PKR memuat keterangan para pihak/ saksi terkait apa yang dia lihat dan ketahui tentang suatu hal atau peristiwa karena akta ini termasuk golongan "Partij Akta" yang dibuat oleh pejabat umum yang diangkat dengan sumpah.

Maka dalam perspektif hukum pidana pembuktian PKR merupakan akta yang otentik karena berkekuatan pembuktian secara sempurna, karena akta ini termasuk alat bukti berupa surat dan termasuk golongan "Partij Akta"dibuat oleh pejabat umum yang diangkat dengan sumpah.

\section{Kekuatan Pembuktian Notaris atas Akta Pernyataan Keputusan Rapat (PKR) Ditinjau dari Hukum Perdata}

Dalam proses peradilan, pembuktian sangat menentukan hasil akhir dari keseluruhan prosed peradilan, berdasarkan tahap pembuktian dapat diketahui benar atau tidaknya suatu gugatan (Sugeng, 2010). Pembuktian diupayakan untuk mencari tujuan dari hukum yaitu keadilan, kemanfaatan dan kepastian hukum. Pada proses perkara perdata hukum memiliki tujuan menyelesaikan suatu sengketa dengan dalil dan memberi suatu kepastian hukum bagi para pihak yang berperkara. Proses peradilan perdata menuntut adanya suatu kebenaran absolut. Mencari kebenaran yang sangat suli disebabkan oleh beberapa faktor, antara lain (Harahap, 2008):

a. Faktor adversarial (adversarial system);

b. Kedudukan hakim dalam proses pembuktian dengan sistem adversarial lemah dan pasif.

c. Mencari dan menemukan kebenaran semakin lemah dan sulit, disebabkan fakta dan bukti yang diajukan para pihak tidak dianalisis dan dinilai oleh ahli.

Berdasarkan Pasal 1866 KUHPerdata terdapat beberapa macam alat bukti yaitu: Alat bukti surat; Saksi; Pengakuan; Persangkaan; Sumpah. Jika dianalisis Pasal 1866 KUHPerdata tentang jenis-jenis alat bukti maka akta Pernyataan Keputusan Rapat (PKR) termasuk alat bukti surat atau tertulis, hal ini terkait bentuk fisik dari akta tersebut yang tertulis dan dapat dijadikan sebagai alat bukti dalam persidangan secara tertulis.

PKR sebagai alat bukti merupakan alat bukti surat atau tulisan karena bentuknya tertulis. Alat bukti surat terbagi menjadi tiga yaitu akta otentik, akta dibawah tangan dan surat. PKR merupakan hasil keputusan Rapat Umum Pemegang Saham (RUPS) yang dibuat di bawah tangan dan kemudian dituangkan ke dalam akta otentik, sesuai de- 
ngan Pasal 21 Ayat (4) UUPT, yang akan membawa akibat hukum, yakni otentiknya akta tersebut.

Berdasarkan Pasal 1868 KUHPerdata PKR tersebut merupakan salah satu jenis akta otentik "Partij acta" yang mana PKR merupakan hasil dari notulen RUPS yang dibuat secara dibawah tangan kemudian dituangkan dalam akta Notaris. Hal tersebut diberikan kuasa dari Perseroan Terbatas yang bersangkutan dari RUPS. Penerima kuasa tersebut dapat menghadap Notaris dalam rangka pembuatan PKR. Notaris terlibat dalam pembuatan keputusan RUPS karena keputusan itu dibuat oleh para pihak dalam perjanjian berdasarkan kesepakatan mereka dan kemudian dituangkan kedalam akta notaris.

Akta Pernyataan Keputusan Rapat (PKR) mengenai perubahan anggaran dasar dapat dikategorikan sebagai akta notariil, namun isinya merupakan risalah rapat di bawah tangan. Akta Pernyataan Keputusan Rapatnya mempunyai pembuktian yang mengikat dan sempurna, seperti akta Notaris yang bersifat akta pihak "Partij Akta". Hal ini karena apa yang ditulis dalam akta tersebut terbukti kebenarannya dan dianggap benar oleh hakim, selama ketidakbenarannya dapat dibuktikan sempurna, maka akta tersebut sudah tidak memerlukan lagi suatu penambahan pembuktian, sementara isinya dapat dikatakan memiliki pembuktian sempurna bila tanda tangan dalam risalah rapat di bawah tangan tersebut diakui oleh para pihak dan tidak menjadi sengketa.

Akta RUPS yang dibuat dengan notulen RUPS dibawah tangan, merupakan akta otentik yang memiliki kekuatan pembuktian yang sempurna. Akta ini termasuk alat bukti otentik (Pasal 1866 KUHPerdata) golongan "Partij Akta" yang dimana terhadap pembuktian sebaliknya dapat digugat, dengan cara menyatakan bahwa keterangan dari para pihak diuraikan secara lengkap dalam akta itu, namun keterangannya tidak benar, sehingga keterangan yang diberikan itu dapat dilakukan pembuktian sebaliknya (Tobing, 1996).

\section{Simpulan}

Kesimpulan dari hasil penelitian dan pembahasan atas permasalahan tersebut di atas, bahwaTanggung jawab notaris terhadap akta Pernyataan Keputusan Rapat (PKR) berdasarkan kesalahan sesuai dengan Pasal 1365 KUHPerdata dan sebatas kebenaran formal saja, sedangkan mengenai kebenaran isi akta tersebut menjadi tanggung jawab para pihak/pihak yang menghadap Notaris, karena Notaris tidak mengetahui dan menghadiri jalannya RUPS tersebut.

Kekuatan pembuktian atas akta Pernyataan Keputusan Rapat (PKR) ditinjau dari Hukum Pidana merupakan alat bukti yang sempurna karena sesuai dengan Pasal 187 KUHAPidana. Sedangkan kekuatan pembuktian ditinjau dari Hukum Perdata merupakan alat bukti otentik (Pasal 1866 KUHPerdata) golongan "Partij Akta" yang dibuat dihadapan notaris yang diangkat dengan sumpah dan terhadap pembuktian diperkenankan pembuktian sebaliknya.

\section{Saran}

Berdasarkan kesimpulan tersebut di atas, maka penulis memberikan saran, yaitu: Notaris sebagai pejabat pembuat akta otentik hendaknya berhati-hati dalam membuat akta otentik, harus berpegang teguh pada UUJN terkait kewenangan, kewajiban, larangan agar tidak mengakibatkan kerugian pada klien juga pada notaris sendiri.

\section{DAFTAR PUSTAKA}

H.R., Ridwan. 2006. Hukum Adminitrasi Negara. Raja Grafindo Persada. Jakarta.

Harahap, M. Yahya. 2008. Hukum Acara Perdata. Sinar Grafika. Jakarta.

Hiarej, Eddy O.S. 2012. Teori E Hukum Pembuktian. Erlangga. Jakarta. 2012.

Kansil. 1996. Pokok-Pojok Hukum Perseroan Terbatas. Pustaka Sinar Harapan. Jakarta. 


\section{Tanggung Jawab Notaris Atas Akta Pernyataan Keputusan Rapat}

Jonathan Adi Biran Munandir \& Thohir Luth

Kitab Undang-Undang Acara Pidana.

Kitab Undang-Undang Perdata.

Kitab Undang-Undang Pidana.

Peraturan Menteri Hukum dan Hak Asasi Manusia Republik Indonesia Nomor M-01-HT.01-10 Tahun 2007 Tentang Tata Cara Pengajuan Permohonan Pengesahan Badan Hukum dan Persetujuan Perubahan Anggaran Dasar, Penyampaian Pemberitahuan Perubahan Anggaran Dasar dan PerubahanData Perseroan.

Rianggono, Bambang. 2007. Kekuatan Akta Pernyataan Keputusan Rapat (PKR) Yang Dibuat Berdasarkan Risalah Rapat Di Bawah Tangan Ditinjau dari Tanggung Jawab Notaris. Tesis Magister Kenotariatan Fakultas Hukum Universitas Diponegoro Semarang.

Siswandi. 2017. Problematika Penggunaan Rekaman Closed Circuit Television (CCTV) Sebagai Alat Bukti Dalam Perkara Pencurian Dihubungkan Dengan Kuhap Jo Undang-Undang No. 19 Tahun 2016 Tentang Informasi dan Transaksi Elektronik. Skripsi Fakultas Hukum Universitas Pasundan Bandung.

Sofyan, Andi \& Abd. Asis. 2014. Hukum Acara Pidana. Prenada Media Group. Jakarta.
Sugeng,Bambang. 2010. Pengantar Hukum Acara Perdata Contoh Dokumen Litigasi". Kencana Group. Jakarta.

Tobing, G.H.S. Lumban.1996. Peraturan Jabatan Notaris. Erlangga.Jakarta.

Undang-Undang Republik Indonesia Nomor 2 Tahun 2014 Tentang Perubahan Atas Undang-Undang Republik Indonesia Nomor 30 Tahun 2004 Tentang Jabatan Notaris. Lembaran Negara Republik Indonesia Nomor 3 Tahun 2014 dan Tambahan Lembar Negara Republik Indonesia Nomor 5491. Jakarta.

Undang-Undang Republik Indonesia Nomor 40 Tahun 2007 Tentang Perseroan Terbatas. Lembaran Negara Republik Indonesia Tahun 2007 Nomor 106 dan Tambahan Lembaran Negara Republik Indonesia Nomor 4756. Jakarta.

\section{How to Cite:}

Munandir, Jonathan Adi Biran \& Thohir Luth. 2017. Tanggung Jawab Notaris Atas Akta Pernyataan Keputusan Rapat. Jurnal Cakrawala Hukum. 8 (1): 55-63. 